DOI 10.18551/rjoas.2019-10.17

\title{
TRADITIONAL MARKET MANAGEMENT STRATEGY IN CONDITIONS OF MODERN MARKET DEVELOPMENT
}

\author{
Iriani Sri Setyo, Sanaji \\ Department of Management, Faculty of Economy, University of Negeri Surabaya, Indonesia \\ *E-mail: srisetyo@unesa.ac.id
}

\begin{abstract}
The dynamics of trading in the people's markets is a reflection of the economic growth of a region. Therefore, with the rapid growth of modern markets, it becomes a big challenge for traders in the market. Modern market conditions that have many advantages in terms of facilities and services, make people prefer shopping in the modern market to the people's market. The method used in this research is descriptive qualitative through SWOT analysis which is used as the basis for strategy formulation. Therefore, a management strategy is needed to improve the competitiveness of traditional markets, by improving management insight, entrepreneurial mind-set for market managers and sellers, renovating old buildings, increasing the cleaning and security services, as well as creating planning and performance evaluation.
\end{abstract}

\section{KEY WORDS}

Traditional market, modern market, entrepreneurial mind-set, public service.

Trade activities in the community show the stretching of a region's economy. Activities in the people's market are one part that forms trade activities, especially among people with lower economic levels. Therefore, the existence of the people's market is still very necessary to maintain the people's economy which is one of the characteristics of the Indonesian economy. The resilience and survival of the people's markets has a considerable influence on the national economy because in this market mobilization of agricultural products, plantations, livestock and other small businesses takes place. In Indonesia, who is the manager will determine the shape and structure of the market, namely the regional market managed by the regional government and the village market managed by the village government market.

But the results of A.C Neilson's survey (2006) actually show that the people's market has decreased by $8 \%$ while the modern market has grown by $31.4 \%$. This condition continues as stated in discussions on the revitalization of the people's market at the Ministry of Trade on April 23, 2012 that the people's market experienced negative growth of $8.1 \%$. The Republika daily further commented that it was estimated that 12 years from now the people's market would become a museum (Republika, 2018). This condition is important for the province of East Java because East Java has the largest public market in Indonesia, which is 1,823 units.

Researchers' observations in the field show that the physical condition and services of people's markets are one of the triggers for the decline in people's market performance. The presence of modern retailers such as Indomaret and Alfamart has changed the lifestyle of people who prefer shopping in the modern market rather than in the traditional market. The government has made various efforts to revitalize the people's market but until now it has not been able to improve the performance of the people's market. One of them was as stated by President Jokowi during the inauguration of 6 traditional markets in Pontianak in 2017. He stressed that the existence of the people's market now is the time to improve both physically and its management so that it has competitiveness in generating the wheels of the economy which in the long run are able to support regional income sources. In line with the direction of the Economic Development Policy which currently has 3 (three) main pillars, including Land, Opportunities, and Human Resource Capacity (HR). Of the three main pillars, there are 10 fields which are considered to be a source of inequality in the community. The First 
Pillar based on land will include agrarian reform and social forestry; agriculture in relation to the issue of landless farmers; plantations associated with low productivity and value added commodities; affordable housing for the urban poor; and fishermen and seaweed farming farmers. The second pillar based on opportunity will target tax system problems; manufacturing and information technology; development of retail and traditional markets; and financing with government funds. While the third pillar, namely increasing human resource capacity, is targeted at resolving vocational, entrepreneurial and labor market issues.

The second pillar states that the opportunity to resolve the existing problems in the people's market is a priority scale so that the people's market is no longer a slum, insecure market, poor arrangement system, and inadequate infrastructure. Therefore the people's market needs to be managed professionally and in accordance with national standards. Good management will have a positive impact, among others, the economy of the community grows, retribution increases, multiplier grows, unemployment decreases, and welfare increases.

The setting of this study is in one area in East Java Province, namely Sidoarjo Regency where the number of people's markets is not commensurate with the development of modern retail. The Regency has a number of people's markets managed by the local government of 18 markets where the number of modern retail reaches 765 outlets. This phenomenon shows that the people's market is demanded to develop sustainable future development strategies. Fred David (2000) states that this strategy is an important effort in developing an organization which is carried out in three stages, namely: Strategy formulation, strategy implementation and strategy evaluation. This research tries to propose the formulation of strategies made through this stage. Through these stages, the formulation of strategies can clarify the direction of management of public markets.

\section{LITERATURE REVIEW}

Economic development is a process of increasing total income and income per capita by taking into account population growth and accompanied by fundamental changes in the economic structure of a country and income distribution for residents of a country. Economic development is closely related to economic growth, because economic development can encourage economic growth and economic growth can facilitate the process of economic development. The government continues to strive to increase national economic growth in order to overcome inequality in society. One of them is through the Economic Equity Policy program which President Joko Widodo has delivered, which is based on three pillars, namely land, opportunity and human resources. In the second pillar, namely the opportunity, one of which is targeting the development of retail and public markets.

People's market is an important thing in people's lives. Many people who need markets in search of income and meet the needs of buying and selling transactions. The management of the people's market can support national economic growth, because the existence of the people's market provides a place for people to buy and sell as farmers and fishermen. The number of people who work as farmers and fishermen is very large, so if the group becomes a strategic sector in developing the national economy, then economic growth will be created.

People's market is a certain area where buyers and sellers meet, directly or indirectly, with the process of buying and selling consumer goods through bargaining. People's markets consist of shops, kiosks, stalls, and / or tents owned / managed by small, medium-sized traders, non-governmental organizations, and / or cooperatives as well as micro, small and medium-sized businesses. Public markets can be arranged, built and / or managed by the Central Government, Regional Government, private sector, cooperatives, state-owned enterprises and / or regionally-owned business entities. People's Market is classified into 4 (four) types, namely: People's Market type A, People's Market type B, People's Market type C, and People's Market type D. People's markets are built based on the provisions that have been set in the guidelines for development and management. Public markets must also be equipped with supporting facilities and infrastructure, at least in the form of a management 
office, toilets, re-measuring posts, security posts, nursing rooms, worship rooms, fire extinguishers, parking lots, and temporary waste storage facilities.

People's market managers have the main duties and functions in terms of carrying out public services in the field of market area management, fostering market traders, helping to stabilize prices and smooth distribution of goods and services in the market. The functions of the market manager include the following:

- Planning, building, maintaining and maintaining market areas;

- Provision, maintenance and maintenance of market area completeness facilities;

- Supervision and control of utilization of market areas;

- Management and development of market areas;

- Guidance of traders in the context of utilizing market areas;

- Assistance to price stability of goods;

- Assistance with the availability and smooth distribution of goods and services;

- Implementation and development of cooperation;

- Control of security and order in the market area.

Work procedures or Standard Operating Procedures (SOP) are available that describe the tasks, work methods and work flow of each position. A well-documented and easily accessible SOP includes:

- Imposition of market fees and taxes;

- Security and order;

- Waste cleanliness and handling;

- Maintenance of market facilities;

- Arrangement of market traders, parking and billboards in the market area;

- Fire Fighting;

- Mechanisms for complaints and handling market management;

- Use of commercial space;

- Sanctions and warnings;

- Supervision to ensure the availability of merchandise that is safe, healthy and free of hazardous materials and meets applicable regulations.

The structure of the people's market management consists of the Head of Market, the Administration and Finance Division, the Order and Security Division, the Maintenance and Cleanliness Division and the Customer Service and Community Development Division.

Local Own Revenue (PAD) is revenue that is sourced and collected by the local government. PAD sources consist of, local taxes, regional levies, profits from regionally owned enterprises (BUMD) and other regional own-source revenues. Regional Original Revenues are used by the regions in implementing the government and developing regions according to their needs in order to minimize dependence on obtaining funds. PAD can be used as additional funds for various routine regional expenditure needs.

One source of local revenue is local user fees. Regional levies are regional levies as usage payments to anyone who utilizes or accepts the services provided by the region. Types of local user fees are public service fees, ie services provided by local governments for the benefit and benefit of the general public.

Market service user fees are one of the public service charges. This market service levy will later be returned for market services in the form of providing adequate market infrastructure. However, in practice the traders in the public market must pay the levy money, where the levy money paid by the trader is not returned to the public market, causing the conditions of the market environment to be slum and not well managed.

Strategic management as defined by Pearce and Robinson (2014) is a series of decisions and actions that result in the formulation and implementation of plans to achieve company goals. Strategic management consists of nine important tasks, namely:

- Formulate the company's mission;

- Conduct analysis that reflects the internal conditions and capabilities of the company;

- Assess the company's external conditions; 
- Analyze the choices that the company has by adjusting its resources to the external environment;

- Identify the most desirable choices by evaluating each option according to the company's mission;

- Choose a set of long-term goals and key strategies that can produce the most desirable choices;

- Designing annual goals and short-term strategies that are consistent with the set of long-term goals and main strategies that have been selected;

- Implement strategic choices according to the resource allocation budget;

- Evaluate the success of the strategic process as input for future decision making.

In deciding the strategy to be chosen by the company, it is important to be able to analyze the company's external and internal conditions. The company's external conditions include: Distant Environment, Industrial Environment and Operating Environment

While internal analysis starts from recognizing the company's internal conditions, both strengths, weaknesses, opportunities and threats for the company. to answer all questions related to internal company using SWOT analysis.

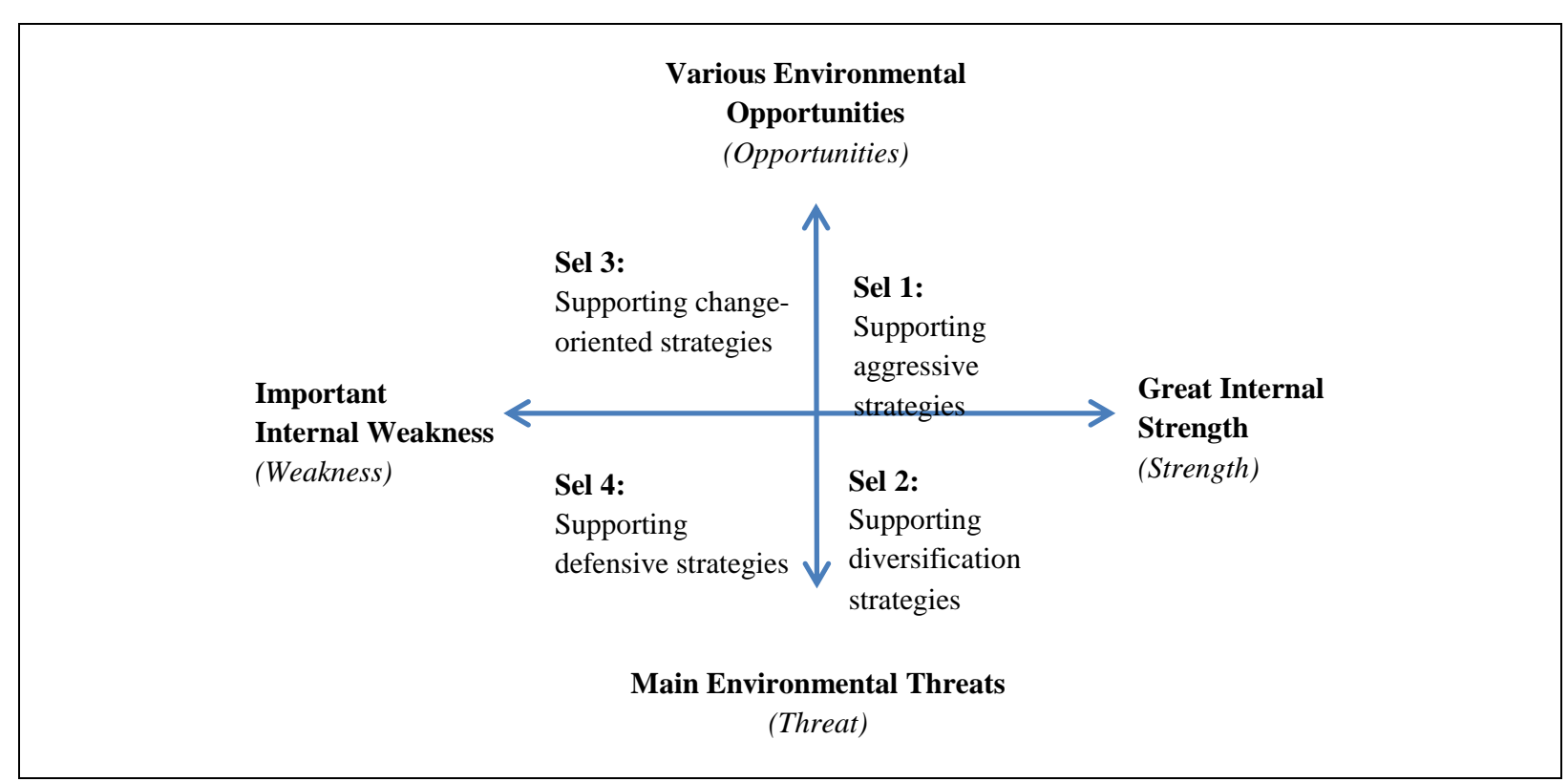

Figure 1 - SWOT matrix

SWOT analysis is a translation of internal strengths and weaknesses as well as opportunities and threats faced by the company. SWOT analysis is used to quickly highlight the situation being faced by the company (Pearce and Robinson, 2014). SWOT analysis is based on the assumption that an effective strategy is derived from a good "fit" between the company's internal resources sourced from the company's strengths and weaknesses, with its external situation in the form of opportunities and threats facing the company.

- Opportunity. Is the main situation that is profitable in a company's environment. Identification of previously missed market segments, changes in competition and regulatory conditions, technological changes, improved relations with buyers and suppliers are opportunities for the company;

- Threat. That is the main unfavorable situation in the environment of a company. entry of new competitors. slow market growth, technological change, is a threat to companies;

- Strength. Is a resource or capacity that is controlled by or available to a company that makes the company superior to its competitors in serving customer needs. The location of the factory which is near raw materials, qualified human resources, better quality products are some examples of the strength of the company; 
- Weakness. Namely the limitations or deficiencies in one or more resources or capabilities of a company relative to its competitors, which become obstacles in meeting the needs of customers effectively.

One of the information used in identifying opportunities and threats in the environment of a company is obtained from conducting environmental and industry analysis.

The results of the mapping on the SWOT matrix will divide the sections into four cells:

- Cell 1 , is the most favorable situation. The company faces various environmental opportunities and has diverse strengths. This situation allows companies to take growth-oriented strategies to exploit these benefits;

- Cell 2, the company has identified several core strengths but faces an unfavorable environmental situation. Companies that face this condition must look for strategies to use the resources and strong competencies that the company has to develop longterm opportunities in a more promising product market;

- Cell 3, companies face impressive market opportunities but are hampered by weak internal resources. Strategies that can be taken are eliminating internal weaknesses so that they can more effectively pursue market opportunities;

- Cell 4, is the most unfavorable situation, where companies face a big threat from the environment because of the position of weak resources. This situation requires a strategy that can reduce or redirect involvement in products or markets that have been reviewed through a SWOT analysis.

Strategy is a tool to achieve long-term goals. Business strategies can include geographical expansion, diversification, acquisition, product development, market penetration, business reduction, divestment, liquidation and joint ventures. Strategy is a potential action that requires top-level management decisions and a large amount of company resources. In addition, the strategy affects the company's prosperity in the long run, especially for five years, and future-oriented. The strategy has multifunctional and multidimensional consequences and needs to consider internal and external factors.

Table 1 - Generic Strategy

\begin{tabular}{|c|c|c|}
\hline Generic Strategy & Main Strategy & Definition \\
\hline Vertical Integration Strategy & $\begin{array}{l}\text { Forward Integration Strategy } \\
\text { Backward Integration Strategy } \\
\text { Horizontal Integration Strategy }\end{array}$ & $\begin{array}{l}\text { Increase control over the distributor } \\
\text { Increase control over company suppliers } \\
\text { Increase control over competitors }\end{array}$ \\
\hline Intensive Strategy & $\begin{array}{l}\text { Market Development Strategy } \\
\text { Product Development Strategy } \\
\text { Market Penetration Strategy }\end{array}$ & $\begin{array}{l}\text { Introducing the product/current services to new geographical } \\
\text { areas } \\
\text { Increase sales through product improvement/service } \\
\text { Increase market share for products /services through greater } \\
\text { marketing }\end{array}$ \\
\hline Diversification Strategy & $\begin{array}{l}\text { Concentric Diversification Strategy } \\
\text { Conglomerate Diversification Strategy } \\
\text { (Conglomerate Diversification Strategy) } \\
\text { Horizontal Diversification Strategy (Horizontal } \\
\text { diversification strategy) }\end{array}$ & $\begin{array}{l}\text { Add new products / services that are still related to old products / } \\
\text { services } \\
\text { Add new products / services that are not related to old products / } \\
\text { services } \\
\text { Add new products / services that are not related to current } \\
\text { customers }\end{array}$ \\
\hline Defensive Strategy & $\begin{array}{l}\text { Joint venture strategy } \\
\text { Retrachment Strategy } \\
\text { Business Shrinking Strategy (Divestiture } \\
\text { strategy) } \\
\text { Liquidation Strategy } \\
\text { Joint Venture Strategy } \\
\text { Retrachment Strategy } \\
\text { Business Shrinking Strategy (Divestiture } \\
\text { strategy) }\end{array}$ & $\begin{array}{l}\text { Work with other companies to increase sales } \\
\text { Re-grouping through the reduction of costs and assets against the } \\
\text { decline in sales and profits } \\
\text { Selling one division or part of the company } \\
\text { Sell all of the company's assets, piecemeal for real value } \\
\text { Working closely with other companies to increase sales } \\
\text { Re-grouping through reducing costs and assets against decreasing } \\
\text { sales and profits } \\
\text { Selling one division or part of the company } \\
\text { Selling all company assets, piecemeal for real value }\end{array}$ \\
\hline
\end{tabular}

According to Chandler (1962), strategy is a tool to achieve company goals in relation to long-term goals, as well as priority allocation of resources. According to Learned, Christensen, Andrews and Guth (1965), strategy is a tool for creating competitive advantage. Thus one focus of the strategy is to decide whether the business must exist or not exist. According to Hamel and Prahalad (1995), strategy is an action that is binding and continuous, and is carried out based on the perspective of what is expected by customers in the future. The speed at which new market innovations and changes in consumer patterns require core competence. Many alternative strategies were chosen for business development 
in various forms. The alternatives include: integration strategy, intensive strategy, diversification strategy and defensive strategy.

\section{METHODS OF RESEARCH}

This research is a descriptive study with a qualitative approach, which describes the internal and external environmental conditions of people's markets in Sidoarjo Regency. Qualitative methods generally take smaller samples and their sampling is purposive rather than random. Qualitative research is more directed towards process research rather than products and tends to be limited to one case. In addition, qualitative research focuses on the depth of data (quality) so that researchers can dig deeper into the object under study (Sukmadinata, 2011: 60).

Data sources includes: primary and secondary data. Primary Data: data obtained through questionnaires and interviews directly to traders and managers. Secondary Data: data on market management policies and other supporting regulations. The object of this research is a market development strategy based on SWOT analysis. The subjects of this study consisted of traders and managers of the People's Market by taking locations in 4 markets in Sidoarjo Regency.

To determine the research subjects in order to capture adequate information from public market traders and offices as market managers, all information will be explored by conducting a deep interview and Focus Group Discussion. The population in this study was 4 people's markets located in Sidoarjo regency. The sample was determined purposively, by determining several characteristics, namely a renovated market with 2017 and 2018 local government budgets.

Data is collected using the following techniques:

- Observation: Observation is done by observing traders in the people's market and the condition of the people's market;

- Interview: The data collection technique was carried out by conducting in-depth interviews to dig up information from the community market traders and the department as the manager of the people's markets in Sidoarjo Regency;

- Questionnaire: Distribution of questionnaires was carried out to dig up information about market profiles, traders and services provided by the Regional Government;

- Documentation: Collection of documents related to regulations, supporting rules regarding market management, retribution rates etc. as well as photos of activities needed in this study;

- FGD: sharing information from the results of research with managers and traders' representatives.

The data analysis technique in this study is the strategic management thinking framework that uses SWOT analysis with the following stages:

- Identification of the vision and mission of the people's market in Sidoarjo Regency;

- Determination of long-term goals;

- Analysis of the internal environment consisting of strengths and weaknesses;

- Analysis of the external environment consisting of opportunities and threats;

- Making a position matrix based on - BCG and also GE;

- Position Determination based on the matrix position calculation;

- Formulating strategies from various matrix positions;

- Selection of alternative strategies for developing people's markets.

\section{RESULTS AND DISCUSSION}

Pasar Taman is located on Jl. Raya Stasiun, Kecamatan Taman, Kelurahan Wonocolo, Sidoarjo Regency, East Java. In Taman District alone with a population density of 158,537 people (population data of Sidoarjo Regency in 2017). Pasar Sepanjang has an area of \pm 
$15,552 \mathrm{M} 2$ with 112 stalls and 1,021 booths. This market is open from $05.00-17: 30$. The Sepanjang Market area is one of the biggest markets in Sidoarjo Regency.

Gedangan Market is one of the trade infrastructure facilities located in Ketajen Village, Gedangan District which is part of the Sidoarjo Market Management Unit. Gedangan Market has an area of 19,555,208 M2 and has an area of 3,128,290 M2 built. The number of booths at Gedangan Market consists of booth booths and kiosk stands. The booths in the Gedangan Market numbered 137 stands with booth conditions around $35 \%$. As for the stalls there are 396 stalls with close to $40 \%$.

Sukodono Market is on Jalan Raya Sukodono No. 18, Sukodono, Sidoarjo Regency. Sukodono Market is part of the UPTD Park and management of Sukodono Market is carried out by several parties. Sukodono Market has an area of 5,855 $\mathrm{m} 2$ and a building area of $1,430 \mathrm{~m} 2$. Sukodono Market Traders consist of permanent traders, ex-terminal traders, and seasonal traders, as well as night field work practices. Sukodono Market operates from 04.00 - 12.00 WIB and 16.00 - 21.00 WIB.

Pasar Baru Porong is located in Juwet Kenongo Village, Porong District, Sidoarjo Regency. This market is built on an area of $68,000 \mathrm{M} 2$, with a building area of 17,786.12 m2. In the Porong market there are 3,263 traders and have the right to use the stalls, togu, and stalls as a place to sell. Pasar Baru Porong has a lot of traders with a number of booths consisting of booths with each number, 50 booths, 299 booths, 2414 booths for loading and unloading approximately 200 and about 300 stretches. Each stall and kiosk is charged Rp. 1,500 per meter, while warehouse stores are charged Rp. 2,000 per meter.

Internal and External Environmental Analysis:

Strength:

- Strategic location with residential and residential areas;

- Easy access from the highway;

- Has adequate parking space;

- Has legal market document ownership;

- Special loading and unloading areas are available;

- Has an adequate management office;

- The location is in accordance with the local RT or RW;

- Provides convenience for the mobility of traders and buyers;

- Close to public facilities such as stations and terminals;

- Number of traders with large merchandise variances;

- Price of goods that can be negotiable;

- Payment can be paid in installments to regular customers;

- An adequate number of human resources;

- As a wholesale / wholesale market center. Weaknesses:

- Most of them are old buildings and have not been arranged well;

- Trader business management is still lacking;

- Limited entrepreneurial spirit of the manager;

- Coaching for traders is still lacking;

- Public facilities are still limited;

- K3 management is not optimal;

- There are many booths that are empty and unorganized;

- Toilet or bathroom is dirty and inadequate;

- The level of cleanliness of the market environment is still lacking;

- Limited area expansion opportunities;

- Many traders do not match their zoning places;

- Hydrant has not functioned optimally;

- Limited and inadequate waste management;

- Many pancake traders are scattered outside;

- The work program is still not well planned; 
- There is no hydrant that functions as a maximum.

Opportunities:

- Increasing community needs;

- Many developing culinary street vendors;

- Consumptive lifestyle of the community;

- Increasing industrial centers;

- Government regulations regarding the development of social economy;

- Public interest in traditional markets.

Threats:

- More and more modern retail stands;

- Modern lifestyle of the people;

- Access to technology.

Table 2 - IFAS and EFAS Matrix

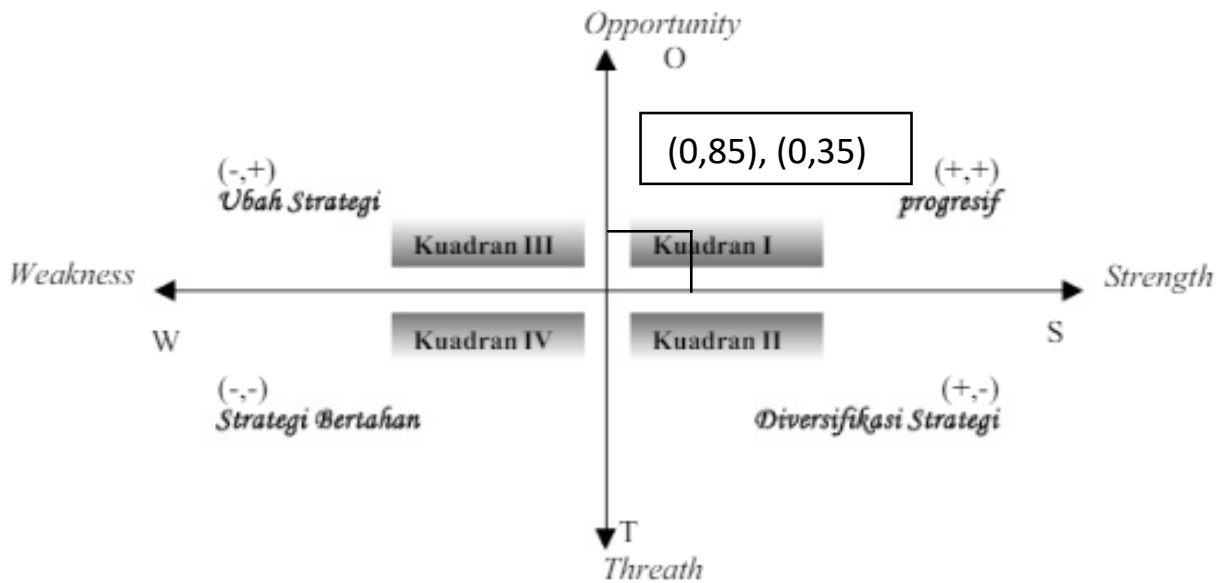

\begin{tabular}{|c|c|c|c|}
\hline \multicolumn{4}{|c|}{ Factor Internal } \\
\hline Strengths & Weight (a) & Rating (b) & Score $\left(a^{*} b\right)$ \\
\hline 1. $\quad$ Strategic location with residential and residential areas & 0,20 & 4 & 0,80 \\
\hline 2. Close to the terminal and station & 0,20 & 4 & 0,80 \\
\hline 3. Number of traders with large merchandise variance & 0,10 & 3 & 0,30 \\
\hline 4. $\quad$ Near residential areas & 0,15 & 3 & 0,45 \\
\hline 5. The price of goods that can be negotiable & 0,05 & 2 & 0,10 \\
\hline 6. Payment can be paid in installments for regular customers & 0,10 & 2 & 0,20 \\
\hline 7. $\quad$ Sufficient number of human resources & 0,10 & 2 & 0,20 \\
\hline 8. As a wholesale / wholesale market center & 0,10 & 3 & 0,30 \\
\hline $\begin{array}{r} \\
\text { Total }\end{array}$ & \multicolumn{3}{|c|}{3,15} \\
\hline Weaknesses & Weight (a) & Rating (b) & Score $\left(a^{*} b\right)$ \\
\hline 1. Many old buildings & 0,15 & 3 & 0,45 \\
\hline 2. Poor level of cleanliness & 0,10 & 3 & 0,30 \\
\hline 3. $\quad$ Limited area expansion opportunities & 0,10 & 3 & 0,30 \\
\hline 4. Los traders who have not been organized & 0,10 & 2 & 0,20 \\
\hline 5. Sanitation & 0,10 & 2 & 0,20 \\
\hline 6. Hidrant has not functioned optimally & 0,05 & 2 & 0,10 \\
\hline Limited waste treatment & 0,10 & 2 & 0,20 \\
\hline 8. $\quad$ Many pancake traders are spread outside & 0,05 & 2 & 0,10 \\
\hline 9. Access road to Pasar Taman has narrow road and prone to traffic jams & 0,15 & 3 & 0,45 \\
\hline 10. $\quad$ Market management mindset and management capabilities are limited & 0,10 & 2 & 0,20 \\
\hline Total & \multicolumn{3}{|c|}{2,30} \\
\hline $\mathrm{X}=$ Strength - Weakness & \multicolumn{3}{|c|}{0,85} \\
\hline \multicolumn{4}{|l|}{ External Factor } \\
\hline Opportunities & Weight (a) & Rating (b) & Score $\left(a^{*} b\right)$ \\
\hline 1. Increasing community needs & 0,30 & 4 & 1.20 \\
\hline 2. Industrial centers in Sepanjang are increasing & 0,20 & 3 & 0,60 \\
\hline 3. Government regulations regarding the development of social economy & 0,25 & 3 & 0,75 \\
\hline 4. Interest in community shopping at traditional markets & 0,30 & 3 & 0.90 \\
\hline Total & \multicolumn{3}{|c|}{3,45} \\
\hline Threats & Weight (a) & Rating (b) & Score $\left(a^{*} b\right)$ \\
\hline 1. The area where Pasar Taman is a flood-prone area. & 0,30 & 4 & 1,20 \\
\hline 2. $\quad$ More and more modern retail stands & 0,20 & 3 & 0,60 \\
\hline 3. $\quad$ Modern lifestyle of the people & 0,30 & 3 & 0.90 \\
\hline 4. Access to technology & 0,20 & 2 & 0,40 \\
\hline Total & \multicolumn{3}{|c|}{3.10} \\
\hline $\mathrm{Y}=$ Opportunity- Threat & & 0,35 & \\
\hline
\end{tabular}


Based on the results of IFAS and EFAS matrix analysis, it can be concluded that the results of the matrix calculation are in quadrant I with the value $X(0.85)$ and $Y$ value $(0.355)$. So the strategy used is the SO strategy that is progressive. The SO strategy in question is (S3O1), namely by conducting promotions and branding.

Strategy Formulation

By looking at the existing position matrix, the alternative strategy is SO, namely progressive. The SO strategy in question is (S3O1), namely by optimizing the strength of the traditional market to take advantage of existing opportunities. So that the real strategy formulations that can be done are:

- Increased management insight for market managers;

- Conduct training for traders regularly;

- Establish an entrepreneurial mindset for managers;

- Increase the entrepreneur mindset of traders;

- Improve market buildings, such as booths, kiosks and main market buildings so that traders and buyers can make transactions comfortably;

- Maintain cleanliness of the market area by providing adequate waste collection facilities;

- Reducing the pancaan traders by moving to booths or kiosks that are still empty in the market;

- Maximizing the function of the fire hydrant so as to be able to absorb water maximally minimize the occurrence of flooding when it rains;

- Provide facilities and infrastructure for waste management to be more effective;

- Organizing promotional events in collaboration with suppliers of suppliers of goods in the market;

- Evaluate market performance;

- Increasing the understanding of K3 management for market managers and traders.

\section{REFERENCES}

1. Dewanti. 2017. 7 Perbedaan Pasar Modern and Pasar Tradisional. (www.materiips.com). (Online) (Accessed on February 12, 2019).

2. Aliyah, I., Daryanto, T.J. \& Rahayu, M.J., 2009. Peran Pasar Tradisional dalam Mendukung Pengembangan Pariwisata Kota Surakarta. GEMA TEKNIK Majalah IImiah Teknik, 10(2), pp.111-118.

3. Azimah, D., Martini, R. and Mannar, G., 2013. Kontribusi Pasar Tradisional and Pasar Modern terhadap Pendapatan Asli Daerah Kota Semarang Tahun 2011 (Studi Kasus di Wilayah Kecamatan Banyumanik). Journal of Politic and Government Studies, pp.138148.

4. Bolos, C., Idemudia, E.C., Mai, P., Rasinghani, M. and Smith, S., 2016. Conceptual Models on the effectiveness of e-marketing strategies in engaging consumers. Journal of International Technology and Information Management, 25(4), p.3.

5. Start, D. and Hovland, I., 2004. Tools for policy impact: a handbook for researchers. London: Overseas Development Institute.

6. David, F., 2005. Strategic management: Concepts and case studies.

7. Oreski, D., 2012. Strategy development by using SWOT-AHP. Tem Journal, 1(4), pp.283291.

8. Giantari, I.G.A.K., Surya, I.B.K., Yasa, N.N.K. and Yasa, I.B.A., 2018. Development and revitalization strategies for traditional markets in Bali. International Journal of Social Economics, 45(7), pp.1058-1070.

9. Hadiwiyono. 2011. Analisis Kinerja Pasar Tradisional di era Persaingan Global di Kota Bogor. Skripsi. Program Studi Manajemen. Pasca Sarjana Institut Pertanian Bogor.

10. http://id.m.wikipedia.org/wiki/Pembangunan-ekonomi (Accessed on February 28, 2018).

11. Imaduddin, M.M. 2014. Business Transformation of Palasari Tradisional Market. Journal of Business and Management. Volume 3. No. 6. pp 682-688 
12. Wiyarni, W., Triyuwono, I., Ludigdo, U. and Djamhuri, A., 2014. Living in Harmony: financial Reporting Objective of Javanese Traditional Market Traders. The International Journal of Accounting and Business Society, 22(1).

13. Nathania, Yoshi. 2018. 6 Perbedaan Pasar Tradisional vs Modern, Kamu Lebih Suka Mana?. (www.idntimes.com). (Online) (Diakses pada 12 Februari 2019)

14. Pearce, J.A. and Robinson, R.B., 2008. Manajemen Strategis: Formulasi, Implementasi, and Pengendalian. Jakarta: Salemba Empat.

15. Purnamasari, A.D. 2014. Analisis Kinerja Operasional Pasar Tradisional Kota Bekasi. Fakultas ekonomi and Bisnis. Semarang: Universitas Diponegoro.

16. Sarwoko, E., 2008. Dampak keberadaan pasar modern terhadap kinerja pedagang pasar tradisional di wilayah Kabupaten Malang. Jurnal Ekonomi Modernisasi, 4(2), pp.97-115.

17. Sirojuddin, Ahmad. 2017. Tiga Pilar Kebijakan Pemerataan Ekonomi Pemerintahan Jokowi. (www.publik.id/artikel/tiga-pilar-kebijakan-pemerataan-ekonomi-pemerintahanjokowi). Accessed on February 28, 2018. www.dpd.go.id/artikel-957-peran-pasartradisional-sebagai-pondasi-dasar-ekonomi-kerakyatan.

18. Sudrajat, A.R., Sumaryana, A., Buchari, R.A. and Tahjan, T., 2018. Perumusan Strategi Pengelolaan Pasar Tradisional di Kabupaten Sumedang. JPPUMA Jurnal IImu Pemerintahan and Sosial Politik Universitas Medan Area, 6(1), pp.53-67. 